\title{
回復期リハビリテーション病棟における薬剤師常駐の必要性と
} 医師・看護師の潜在的なニーズの探索

\author{
藤原久登, ${ }^{*}, a, b, c$ 濃沼政美, ${ }^{c, d}$ 湯本哲郎, ${ }^{c, e}$ 前田拓哉, $c, f$ \\ 上手真梨子, $c, g$ 河原英子, $c, h$ 添田真司, $c, i$ 㴰本 淳, $c, j$ \\ 田村和敬, ${ }^{c, k}$ 中村雅敏, ${ }^{c, l}$ 金田光正, ${ }^{c, m}$ 高尾良洋, ${ }^{c, n}$ \\ 齋藤昌久, ${ }^{c, o}$ 加賀谷 肇, $c, p$ 村山純一郎 $b$
}

\section{Expected Duties of Pharmacists and Potential Needs of Physicians and Nurses on a Kaifukuki Rehabilitation Ward}

\author{
Hisato Fujihara, ${ }^{*, a, b, c}$ Masayoshi Koinuma, ${ }^{c, d}$ Tetsuro Yumoto, ${ }^{c, e}$ Takuya Maeda,,$^{c, f}$ \\ Mariko Kamite, ${ }^{c, g}$ Eiko Kawahara, ${ }^{c, h}$ Shinji Soeda, ${ }^{c, i}$ Atsushi Takimoto, ${ }^{c, j}$ \\ Kazuyoshi Tamura, ${ }^{c, k}$ Masatoshi Nakamura, ${ }^{c, l}$ Mitsumasa Kaneta, ${ }^{c, m}$ Yoshihiro Takao,,${ }^{c, n}$ \\ Masahisa Saito, ${ }^{c, o}$ Hajime Kagaya, ${ }^{c, p}$ and Jun-ichiro Murayama ${ }^{b}$
}

${ }^{a}$ Department of Pharmacy, Showa University Fujigaoka Rehabilitation Hospital; 2-1-1 Fujigaoka, Aoba-ku, Yokohama 2278518, Japan: ${ }^{b}$ Department of Hospital Pharmaceutics, School of Pharmacy, Showa University; 1-5-8 Hatanodai, Shinagawaku, Tokyo 142-8555, Japan: 'Kanagawa Society of Hospital Pharmacists; 14-11 Nishi-machi, Isoko-ku, Yokohama 235-0007, Japan: ${ }^{d}$ School of Pharmaceutical Sciences, Teikyo Heisei University; 4-21-2 Nakano, Nakano-ku, Tokyo 164-8530, Japan: eDivision of Pharmacy Professional Development and Research, Hoshi University; 2-4-41 Ebara, Shinagawa-ku, Tokyo 142-

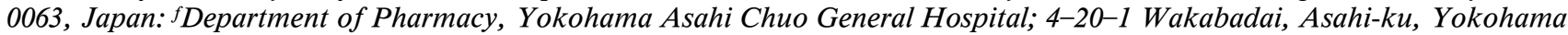
241-0801, Japan: ${ }^{g}$ Department of Pharmacy, Yokohama City University Medical Hospital; 4-57 Urafune-cho, Minami-ku, Yokohama 232-0024, Japan: hDepartment of Pharmacy, Yokosuka Kyosai Hospital; 1-16 Yonegahamadori, Yokosuka, Kanagawa 238-8558, Japan: 'Department of Pharmacy, Tokai University Hachioji Hospital; 1838 Ishikawa-cho, Hachioji, Tokyo 192-0032, Japan: 'Department of Pharmacy, Saiseikai Yokohamashi Tobu Hospital; 3-6-1 Shimosueyoshi, Tsurumiku, Yokohama 230-8765, Japan: ${ }^{k}$ Department of Pharmacy, Kitasato University Hospital; 1-15-1 Kitasato, Minami-ku, Sagamihara 232-0375, Japan: 'Department of Pharmacy, Shonan Atsugi Hospital; 118-1 Nurumizu, Atsugi, Kanagawa 2438551, Japan: ${ }^{m}$ Department of Pharmacy, Seirei Yokohama Hospital; 215 Iwai-cho, Hodogaya-ku, Yokohama 240-8521, Japan: "Department of Pharmacy, Yokohama Municipal Citizen's Hospital; 56 Okazawa-cho, Hodogaya-ku, Yokohama 2400062, Japan: ${ }^{\circ}$ Department of Pharmacy, Odawara Municipal Hospital; 46 Kuno, Odawara, Kanagawa 250-0055, Japan: and ${ }^{p}$ Department of Clinical Pharmaceutics, Meiji Pharmaceutical University; 2-522-1 Noshio, Kiyose, Tokyo 204-0004, Japan.

(Received February 24, 2015; Accepted April 13, 2015)

This study investigated the required duties of pharmacists in a kaifukuki rehabilitation ward from the viewpoint of the ward physicians and nurses. A questionnaire survey was distributed to 27 facilities with kaifukuki rehabilitation wards. The questionnaire examined which duties the physicians and nurses expected from pharmacists while on the ward (4 areas, 10 items), as well as the time required for pharmacists to carry out those duties. Multivariate analysis was used to investigate which types of work took the most time for pharmacists on kaifukuki rehabilitation wards. Responses were received from 43 physicians and 184 nurses who worked on the kaifukuki rehabilitation wards of 19 facilities. The results revealed that the essential duties performed by pharmacists were the management of medical supplies, instruction on the use of self-medicating drugs at the time of introduction, and monitoring drug side effects. Furthermore, some duties, such as the distribution of medicines and changing or suggesting new drugs, required pharmacists to spend extended time on the ward. The responses indicated that physicians and nurses recognized the necessity for pharmacists to perform ward duties along with their routine work. This study shows that physicians and nurses working in kaifukuki rehabilitation wards demand proactive participation from pharmacists in appropriate medical therapy, such as instruction in the administration of medications and assessment at the time of prescription changes.

Key words_ — kaifukuki rehabilitation ward; pharmacist; exploratory data analysis; questionnaire survey

$a$ 昭和大学藤が丘リハビリテーション病院薬局, $b$ 昭和大学薬学部病院薬剤学講座, $c$ 公益社団法人神奈川県病院薬剤師会, $d$ 帝京平成大学薬学部, $e$ 星薬科大学薬剂師職能開発研究部門, $f$ 横浜旭中央総合病院薬剤部, $g$ 横浜市立大学附属市民総合 医療センタ一薬剤部, $h$ 横須賀共済病院薬剂科, $i$ 東海大学医学部付属八王子病院薬剂科, j済生会横浜市東部病院薬剂部, $k$ 北里大学病院薬剤部, l湘南厚木病院薬剂部, $m$ 聖隷横浜病院薬剤課, $n$ 横浜市立市民病院薬剂部, 0 小田原市立病院薬剤 科, $p$ 明治薬科大学臨床薬剤学教室

*e-mail: h-fujihara@cmed.showa-u.ac.jp 


\section{緒言}

回復期リハビリテーション病棟（以下，回復期リ 八病棟）の主たる目的は，急性期治療後の患者が集 中的にリハビリテーションを行い, 日常生活活動 （activities of daily living; ADL）の向上・維持を 図って, 可能な限り在宅復帰を推進することとされ ている. ${ }^{1)}$ また，その対象患者の多くは基礎疾患を 有し, 薬物治療が必須とされる症例も多いことか ら，薬剤師の薬学的管理は不可欠であると考える. しかし，現在，回復期リ八病棟では退院時指導を含 む薬剂管理指導料の算定は認められておらず，病棟 薬剤業務加算においても努力義務の病棟となってい る.さらに「回復期リ八病棟入院料の施設基準」で は，医師，看護師，理学療法士，作業療法士等の記 載はあるが，薬剤師の明記はなされていない. ${ }^{2)} こ$ のような状況の下，回復期リハ病棟においてリハビ リテーションスタッフとともに薬剂師が力を発揮す るためには他職種の潜在的なニーズをとらえ，その ニーズを踏まえたうえで多職種と連携し，効果を示 していくことが重要であると考える.

そこで今回，回復期リ八病棟に薬剤師が常駐する 必要性と回復期リ八病棟を担当する病棟薬剤師への 潜在的な業務ニーズを他職種の視点から探索するた め，回復期リ八病棟に従事する医師及び看護師を対 象とした調査を実施したので報告する.

\section{方法}

\section{1. 調査方法と解析対象施設 公益社団法人神} 奈川県病院薬剂師会が会員 365 施設を対象に実施し た業務調査（調査期間：平成 22 年 12 月-平成 23 年 2 月, 回収率 : $53.7 \%$ ）において「回復期リ八病棟 を有する」と回答した 27 施設の医師及び看護師を 対象として「回復期リハビリテーション病棟におけ る薬剤師のあり方」に対するアンケート調查を実施 した.

調査期間は，平成 23 年 8 月 26 日から 9 月 9 日ま での 2 週間とした。

2. 調査票 調査票は, Fig. 1 に示すように 「回答者属性」,「回復期リ八病棟において薬郕師に 求める業務」,「回復期リ八病棟に薬剤師が必要な場 合の人数と在駐時間」, で構成されている.
2-1.「回復期リハ病棟において薬剤師に求める 業務」

2-1-1. 主要調査項目病棟薬剤師が病棟で業 務としている下記 4 分野 10 項目を選定した.

(1) 投薬

(1)薬剤を患者へ直接渡す，(2)薬剤の服用(使用) 状況を直接患者に確認する

(2) 服薬指導

(3)薬剤自己管理導入時の服薬指導, (4)処方変更 時の服薬指導, (5)副作用のモニタリング

(3) 薬物療法

(6)薬剤の変更や追加の提案，(7)医師に代わって 処方オーダー（院内規約に基づいて），(8)薬剤使 用に関する検査の提案，(9医師に代わって検査 オーダー（院内規約に基づいて）

(4) 薬品管理

(10)病棟内の医薬品の適正管理

2-1-2. 測定尺度 測定尺度として，下記の 4 水準を用いた.

1. 全く不要, 2. 不要, 3. 必要, 4. 非常に必要

なお, 解析の便宜上, 全く不要 (1 点), 不要 (2 点), 必要 (3 点), 非常に必要 (4 点) と 1-4 点に スコア変換したうえで連続尺度として取り扱った。

また，本研究では奇数ではなく 4 水準の偶数の尺 度を用いたが，これは中央を設定せず，どちらかの 傾向を把握することが可能となるためである.

2-2.「回復期リハ病棟に薬剤師が必要な場合の 人数と在駐時間」調查内容を回復期リ八病棟内 スタッフとしての薬剤師の必要性と薬剤師が病棟内 スタッフとして必要な病棟在駐時間とした.

\section{3. デー夕集計・解析}

3-1. 回復期リハ病棟スタッフとして薬剤師を必 要とした医師 · 看護師が薬剤師に求める業務医 師及び看護師が病棟内の薬剤師の必要性に関係する 業務を明らかとするために，目的変数を「週必要時 間（薬剤師が病棟在駐に必要とする時間）」，説明変 数を「病棟薬剤関連業務」10 項目及び評価職種 (医師・看護師：2 水準）として，最小二乗法をあ てはめ重回帰分析を行った。週必要時間は病棟在駐 に必要な薬剂師数（名） ×必要日数 $(/$ 週 $) \times$ 必要 時間（/日）で算出した。なお，必要日数は「毎日」 を 7 (日), 「2〜3 日に 1 日」を 2.5 (日)，「週 1 日 程度」を 1 （日）に，また，必要時間は「丸 1 日」 
Q.1あなたの瞕種について、該当項目にひしてください。

$\square$ 医師

口看護師

（役職：口一般

口主任/係長

看護師長）

口 その他 )

Q.2 薬玮師が下記の業務を病棟内のスタツフとして実施することを想定し、

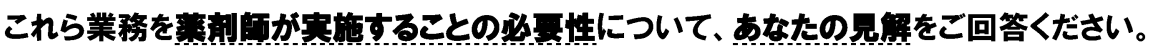

a. 該当する番号に】をつけてください。(1:全く不要 2:不要 3:必要 4:非常に必要)

b. 貴院で既に薬片師が実施している業務があれば】をつけてください。(複数回答可)

\begin{tabular}{|c|c|c|c|c|c|c|c|}
\hline \multirow{2}{*}{$\begin{array}{l}\text { 番 } \\
\text { 号 }\end{array}$} & \multirow{2}{*}{ 分類 } & \multirow{2}{*}{ 藥剤師が病棟で実施すると想定 } & \multicolumn{4}{|c|}{ a.あなたの見解( 必要性) } & \multirow{2}{*}{$\begin{array}{c}\text { b.薬刘師が } \\
\text { 既に実施 }\end{array}$} \\
\hline & & & 1 :全〈不要 & $2:$ 不要 & 3:必要 & 4:非常に必要 & \\
\hline (1) & \multirow{2}{*}{ 投薬 } & 薬剤を直接患者に渡す(配薬) & $\square 1$ & $\square 2$ & $\square 3$ & $\square 4$ & $\square$ \\
\hline (2) & & 薬剂の服用 (使用) 状況を直接患者に確認 & $\square 1$ & $\square 2$ & $\square 3$ & $\square 4$ & $\square$ \\
\hline (3) & \multirow{3}{*}{ 服薬指導 } & 薬刘自己管理導入時 & $\square 1$ & $\square 2$ & $\square 3$ & $\square 4$ & $\square$ \\
\hline (4) & & 処方変更時 & $\square 1$ & $\square 2$ & $\square 3$ & $\square 4$ & $\square$ \\
\hline (5) & & 副作用のモニタリング & $\square 1$ & $\square 2$ & $\square 3$ & $\square 4$ & $\square$ \\
\hline (6) & \multirow{4}{*}{ 薬物療法 } & 薬刘の変更や追加の提案 & $\square 1$ & $\square 2$ & $\square 3$ & $\square 4$ & $\square$ \\
\hline (7) & & 医師に代わって処方オーダー（必要に応じて）* & $\square 1$ & $\square 2$ & $\square 3$ & $\square 4$ & $\square$ \\
\hline (8) & & 薬刘使用に関する検查の提案 & $\square 1$ & $\square 2$ & $\square 3$ & $\square 4$ & $\square$ \\
\hline (9) & & 医師に代わって検㚗オーダー（必要に応じて）* & $\square 1$ & $\square 2$ & $\square 3$ & $\square 4$ & $\square$ \\
\hline (10) & 薬品管理 & 病棟内の医薬品の適正管理（主に在庫管理等） & $\square 1$ & $\square 2$ & $\square 3$ & $\square 4$ & $\square$ \\
\hline
\end{tabular}

※院内ガイドラインや、院内規約に基づいたものとする

Q.3病棟内にスタッフとして薬剤師が必要だと思いますか？該当項目にひしてください。

口必要 .......1)をこ回答〈ださい

口必要でない .....2) をご回答ください

1） Q.1において、おなたの見解に基づく業務を薬削師が実施するとした場合、病棟内にスタッフとして、 何名の薬剤師がどの程度の時間在駐することが必要だと思いますか？

該当項目にひをつけ、文章を完成させてください。

薬唷師 $\left\{\begin{array}{l}\square \text { 1名 } \\ \square \text { 2名 } \\ \square \text { 3名 }\end{array}\right\}$ が $\left\{\begin{array}{l}\square \text { 毎日 } \\ \square \text { 2 3日に1日 } \\ \square \text { 週1日程度 }\end{array}\right\}$ 病棟内に $\left\{\begin{array}{l}\square \text { 丸1日 } \\ \square \text { 半日程度 } \\ \square \text { 1 2 2時間程度 }\end{array}\right\}$ いることが必要である

2) 病棟内にスタッフとして薬用師が必要でない理由について、該当項目にひしてください。(複数回答可)

口 藥玮師がいなくても業務は回る

口病棟内の業務に支障をきたす可能性がある

$\square$ 経営面から

○他( )

こ協力誠にありがとうございました。

神奈川県病院薬郕師会 業務検討委員会

Fig. 1. Questionnaire Survey of the Duties of the Pharmacist in a Kaifukuki Rehabilitation Ward 


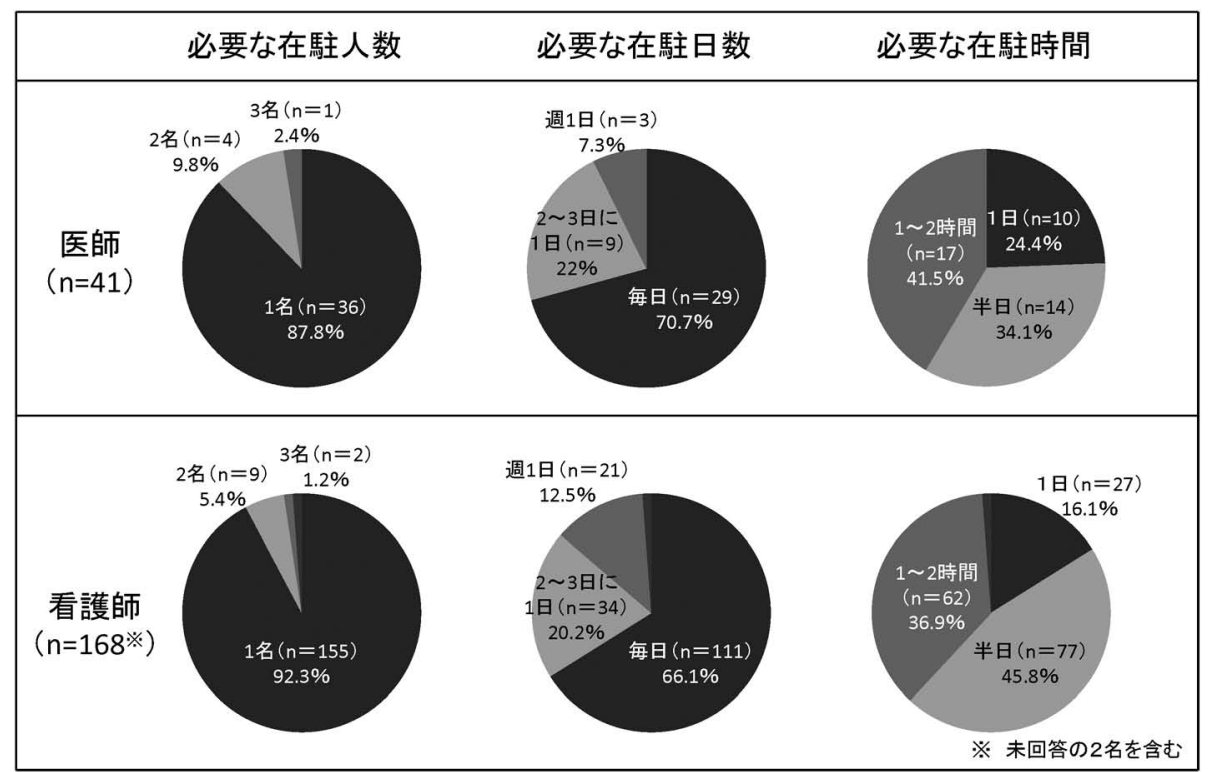

Fig. 2. Questionnaire Results concerning the Presence of the Pharmacist in the Ward

を 7 (時間)，「半日程度」を 3.5 (時間)，「1〜2 時 間程度」を 1.5 (時間) に変換し, 算出した。また, モデルに加える説明変数の選択方式は, 変数削除の 基準 $p>0.05$ としたステップワイズ変数減少法を採 用した。 また, 多重共線性の問題を排除するため, 説明変数間の相関係数を確認し, 分散拡大要因 (variance inflation factor; VIF) の算出を行った. なお, 重回帰式構築のため目的変数に対して対数, 指数, Johnson SI 分布を当てはめ, 分布の正規性 を確保する試みを行った。

有意性の評価は $p<0.05$ を有意差ありとした.

3-2. 布置図の作成各設問の位置関係を視覚 化するために，アンケートの各設問項目における標 準偏差を縦軸, 平均值を横軸にして，2 次元座標に プロットした。平均值及び標準偏差は医師と看護師 の評点の合計值のものとした。

4. ソフトウェア 本研究のすべての統計解析 には JMP ${ }^{\circledR} 9$ (SAS Institute）を使用した。

結果

1. 回答状況調査票の回収率は $70.4 \% （ 19 /$ 27 施設）であり，19 施設のうち 15 施設（回収率 $78.9 \%$ ）の医師 43 名, 19 施設のうち 17 施設（回 収率 $89.5 \%$ ）の看護師 184 名から有効回答を得た。

2. 集計回復期リハ病棟内にスタッフとして 薬剤師が必要と答えた医師は 41 名 $(95.3 \%)$, 看護
師は 168 名（91.3\%）であった。そのうち，必要な 在駐日数を「毎日」と答えた医師，看護師はそれぞ れ 29 名 $(70.7 \%) ， 111$ 名 $(66.1 \%)$ と最も多かつ た. 必要な在駐時間を「1日」若しくは「半日」と 答えた医師，看護師はそれぞれ 24 名 (58.5\%)， 104 名 (61.9\%) であった (Fig. 2).

また，病棟業務 4 分野の業務必要度では，医師， 看護師ともに「薬剤自己管理導入時の服薬指導」 （医師 : $3.48 \pm 0.55$, 看護師 : $3.66 \pm 0.54$ )「病棟内 の医薬品の適正管理」（医師：3.51 \pm 0.59 , 看護師 : 3.54土0.55) が高值であつた (Table 1).

2-1. 回復期リハ病棟スタッフとして薬剤師を必 要とした医師 · 看護師が薬剤師に求める業務方 法に従い，重回帰分析を実施した結果，モデルとし て有意な回帰式を得ることができた（Table 2)，な お, 目的変数の正規分布化に対しては, Johnson SI 分布を当てはめた。この結果より, 医師, 看護師が 薬剤師の病棟在駐時間を長く求める要因として, 「薬剂を患者へ直接渡す」,「薬剂自己管理導入時の 服薬指導」, 「薬剂の変更や追加の提案」の 3 因子が 影響していることが確認された. なお, 各説明変数 のVIFを算出したところ，いずれも 5 以下であ り，多重共線性の影響はないと考えられた。

2-2. 布置図の作成薬剂師業務への要望が最 も大きかつた項目は「薬剤自己管理導入時の服薬指 導」で平均值は 3.62 であった。ついで,「病棟内の 
Table 1. Four Areas of Expected Duties for Pharmacists in a Kaifukuki Rehabilitation Ward

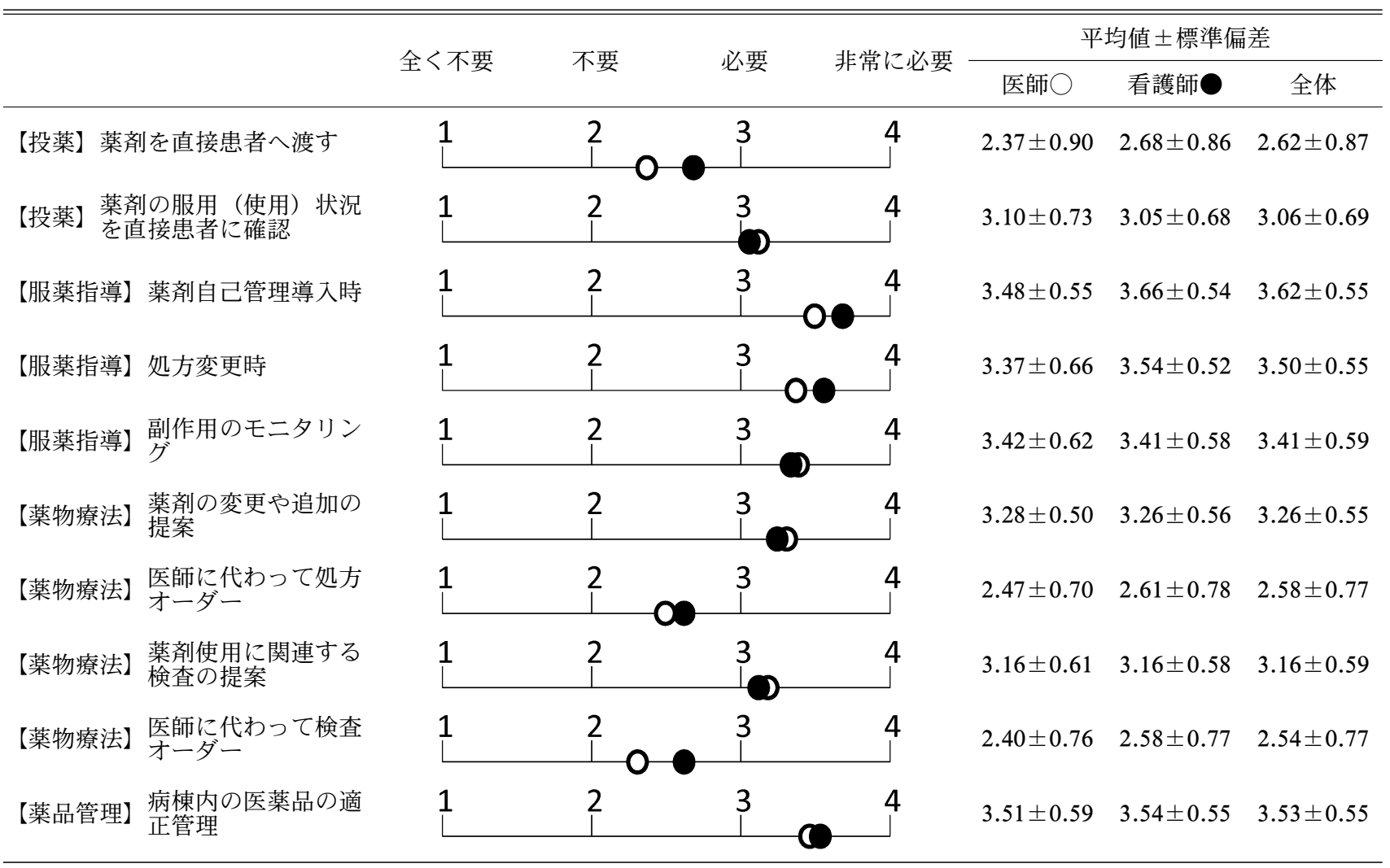

※病棟業務 4 分野: 投薬, 服薬指導, 薬物療法, 薬品管理

Table 2. Factors Which Require the Pharmacist to Be Present in the Kaifukuki Rehabilitation Ward for an Extended Time

\begin{tabular}{|c|c|c|c|c|}
\hline 項 & 推定値 & 標準誤差 & $t$ 值 & $p$ 值 \\
\hline 切片 & -40.30 & 12.33 & -3.27 & 0.0013 \\
\hline $\begin{array}{c}\text { (1)【投薬】薬剤を患者 } \\
\text { 几直接渡す }\end{array}$ & 5.41 & 1.72 & 3.15 & 0.0019 \\
\hline $\begin{array}{l}\text { (3)【服薬指導】薬荗自 } \\
\text { 己管理導入時 }\end{array}$ & 5.83 & 2.68 & 2.18 & 0.0308 \\
\hline $\begin{array}{l}\text { (6)【薬物療法】薬剤の } \\
\text { 変更や追加の提案 }\end{array}$ & 8.01 & 2.69 & 2.97 & 0.0033 \\
\hline
\end{tabular}

モデルの分散分析 $(F=12.71, p<0.0001)$

医薬品の適正管理」(平均値：3.53), 「処方変更時 の服薬指導」(平均值：3.50), 「副作用のモニタリ ング」(平均值：3.41）であった。また，回答者間 のばらつきが最も大きかつた項目は「薬剤を患者へ 直接渡す」で標準偏差は 0.87 であった。また，ば らつきが小さかった項目は「薬剤自己管理導入時の 服薬指導」や「薬剤の変更や追加の提案」で標準偏 差は 0.55 であり，これらの項目が回答者に共通し た認識であることが明らかとなつた（Fig. 3).
考察

平成 24 年度診療報酬改定より病棟薬剂業務実施 加算が新設され，薬剤師が病棟常駐し易い環境が整 いつつある．病棟薬剤業務実施加算の算定要件では 「すべての病棟の入院患者を対象」とする一方で, 「病棟薬剂業務実施加算は特定入院料に含まれるた め，特定入院料を算定する病棟の薬剤師配置は努力 義務」とされている．回復期リ八病棟も特定入院料 を算定する病棟の 1 つであり, 病棟薬剤師の配置は 義務ではない，さらに回復期リ八病棟は，薬剤管理 指導料が算定対象外であり，一般病棟と比較して病 棟業務に必要な人員の確保や配置に困窮する状況に ある。一方，回復期リ八病棟では十分なモニタリン グを必要とする血液凝固阻止剤やジギタリス製剤等 の投与を急性期病棟で開始して間もない患者も多 く, ${ }^{3)}$ 薬物療法の安全性を確保するためには，一般 病棟同様の薬剤師業務が不可欠と考える.

本研究は, 医師, 看護師を対象としたアンケート 結果によって得られたデータに基づき，回復期リハ 


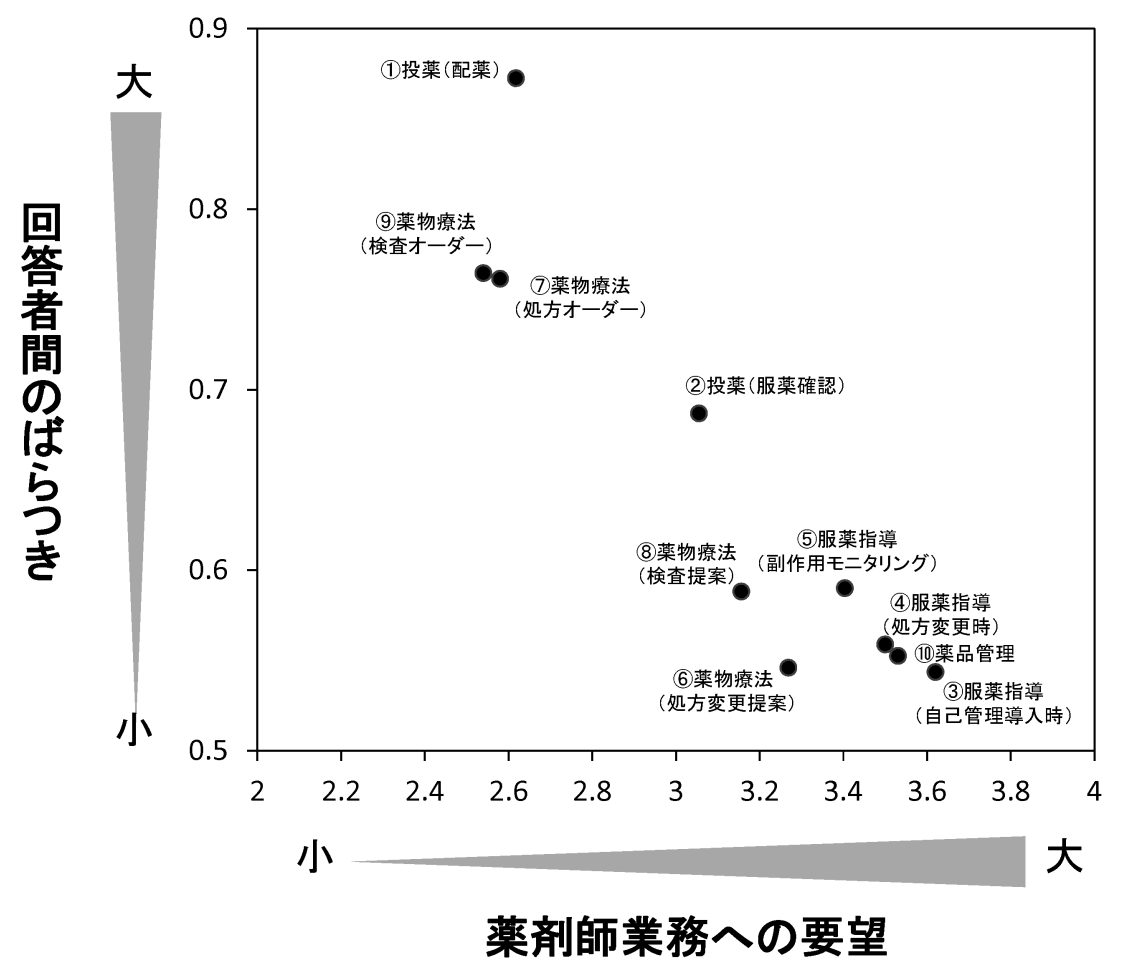

Fig. 3. The Duties That Physicians and Nurses Demand from the Pharmacist in a Kaifukuki Rehabilitation Ward

病棟に薬剤師が常駐する必要性と回復期リハ病棟を 担当する病棟薬剤師への潜在的な業務ニーズを他職 種の視点から探索するため, デー夕解析を行った. その結果, 回復期リハ病棟内にスタッフとして薬剤 師が必要と答えた医師，看護師のうち，必要な在駐 日数を「毎日」と答えた医師, 看護師が最も多く, 過半数の医師，看護師が必要な在駐時間を「1日」 若しくは「半日」と回答していた。これは，医師及 び看護師が必要と考えている薬剂師の病棟在駐時間 が「 1 病棟・ 1 週間当たり 20 時間」に近似しており, 平成 24 年度の診療報酬改定で新設された, 「病棟薬 剂業務実施加算」の施設基準と比べ，ほぼ等しかつ た。一般病棟と同様, 回復期リ八病棟に薬剤師が在 駐し薬剂の責任者としてチーム医療の一員として参 加を求めていると考えられた.

病棟業務 4 分野の業務必要性に関する調査では, 服薬指導や薬品管理とともに「薬剤の変更や追加の 提案」,「薬剤使用に関連する検査の提案」が高值で あった。これは, 薬物療法において薬剤師の関与は 不可欠であり, 薬剤師の知識や技能を駆使して適正 な薬物療法が遂行されることを望んでいると考えら れた. 本結果において医師, 看護師の回答は類似し ており, ともに薬剤師が薬物療法へ関与するニーズ
が高いと判断できる.

医師，看護師が薬剂師の病棟在駐時間を長く求め ている因子を探索した結果，有意に関連した項目は 「薬剂を患者へ直接渡す」,「薬剤自己管理導入時の 服薬指導」,「薬剤の変更や追加の提案」の 3 要因で あった. 平成 26 年 6 月より薬剂師法第 25 条の 2 が 施行され, 患者及び直接患者の看護にあたるものに 「薬学的知見に基づく指導を行わなければならない」 こととなった．薬剤師業務への要望として必要度の 低い「薬剤を患者へ直接渡す」が病棟在駐時間に寄 与する因子として抽出されたが，これは薬剤師が患 者へ薬剤を渡す際, 添付文書と関連する学術論文を 吟味して得た薬学的知見を活用して療養に必要な情 報を提供している日常の業務が医師, 看護師の薬剂 師に求めるニーズとよい一致をみられたと考えられ た，本項目に関しては，医師，看護師間で回答の平 均値の差が最も大きく, 母集団に対する看護師の影 響が大きいと考えられる点を留意した上で, 結果の 解釈を行う必要がある. 今後の研究では, サンプル 数を増やし, さらに本研究結果を参考として対象者 毎に質問項目を調整した上で解析する必要があると 考えられた。 また, 本解析結果より, 医師及び看護 師は薬剤師の病棟業務が必要であることを日常の業 
務を通じて実感しており，配薬や服薬指導といつた 業務も重要であるが，時間的制約を無視すれば，処 方の変更や追加といつた適正な薬物療法への積極的 な関与を求めていると考えられた。

回復期リ八病棟に入院している患者の疾病悪化や 再発の予防，そして在宅復帰，社会復帰のためには 薬剤の自己管理は重要なセルフケアである. ${ }^{4)}$ 布置 図の作成で薬剤師業務への要望が最も大きかった項 目は「薬剂自己管理導入時の服薬指導」であり, 「処方変更時の服薬指導」,「副作用のモニタリング」 が高值であった。特に自己管理導入時の服薬指導は 患者のその後の服薬状況に影響を与えるため, 薬剤 師による服薬指導に医師と看護師の期待が寄せられ ていると考えられた。

これまで, 回復期リ八病棟と一般病棟の両方を併 設する施設において，薬剤師の病棟業務内容の違い を明らかにすることを目的に行った調査では，回復 期リ八病棟に従事する薬剂師の業務において「検査 值チェック」や「副作用のモニタリング」など，継 続した患者モニタリングが必要となる業務の実施度

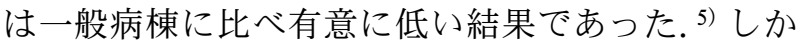
し，今回の調査結果から医師，看護師は服薬指導や 病棟内薬品の管理などの従来の薬剤師業務に加え, 「副作用のモニタリング」を病棟内スタッフとして 薬剤師に求めていることが確認できた。副作用モ二 タリングを徹底するために，薬剤師は患者の状態を 常に観察している医師や看護師と連携して薬学の視 点から観察することが不可欠であり，必要に応じカ ンファレンス等で患者の状況を確認し, 患者に有用 性の高い処方を提案すべきである.

また，最も標準偏差が高かった項目は「薬剤を患 者へ直接渡す」であつた，病棟業務 4 分野の業務必 要度の調査では，医師において本項目が最も低い值 であった。これは「薬剤を患者へ直接渡す」ことが 「療養上の世話」の一部であり，看護師の業務であ ると認識している回答者が多く, 薬剤師業務の必要 度が低く，かつ，ばらつきが多くみられたと考えら れる。

これまでのわれわれの調査では，回復期リハ病棟
に従事する薬剤師は，診療報酬上の評価がなされて いない状況下にもかかわらず，安全管理が必要な医 薬品における服薬指導の必要性や重要性を認識し, 可能な範囲で薬学的管理を実施していることが確認 されている. 5) 本研究により，回復期リ八病棟に従 事する医師及び看護師が薬剤師に求めている業務を 知るとともに，薬剤師常駐の必然性を評価している ことが明らかとなった。

今後, 特定入院料を算定する病棟においても病棟 薬剂師配置の重要性を示していく必要があると考え る.

なお，本研究は回復期リハ病棟を有する施設を対 象に調査を行ったが，さらに結果の精度を高めるに は，回復期リ八病棟数や病床数などの施設間の違い による比較検討を行う必要がある. 今後さらに対象 施設数を増やし, 調査を行うことを課題にしたい.

謝辞アンケート調查に協力して頂きました医 師，看護師の皆様方，神奈川県病薬会員の皆様方に 深くお礼申しあげます。

利益相反＼cjkstart開示すべき利益相反はない.

\section{REFERENCES}

1) Ishikawa M., Nippon Rinsho, 64, 774-777 (2006) .

2) "Shinryotensuhayamihyo," Igakutsushinsya, Tokyo, 2012, p. 865.

3) Akuzawa M., Nakane T., Sekiguchi H., Mihara B., JMC, 19(3), 87-91 (2011).

4) Ochiai K., Aoki M., Yazawa T., Komuro R., Kobayashi E., Kaneko S., Acta Scientiarvm Valettvdinis Universitatis Praefectvralis Ibarakiensis: ASVPI, 9, 21-35 (2004) .

5) Fujihara H., Koinuma M., Yumoto T., Maeda T., Kaneda M., Ayabe Y., Iida J., Kojima M., Kaneda M., Nakayama H., Takao Y., Saito M., Kagaya H., Murayama J., J. Jpn. Soc. Hosp. Pharm., 49, 975-980 (2013). 